OPEN ACCESS

Edited by:

Aurelio Ciancio

Consiglio Nazionale Delle Ricerche

(CNR), Italy

Reviewed by:

Matthew G. Bakker

Agricultural Research Service (USDA),

United States

Luis V. Lopez-Llorca,

University of Alicante, Spain

*Correspondence:

Paola Durán

paola.duran@ufrontera.c

María J. Pozo

mjpozo@eez.csic.es

Specialty section:

This article was submitted to

Plant Microbe Interactions,

a section of the journal

Frontiers in Microbiology

Received: 19 April 2017

Accepted: 31 July 2017

Published: 15 August 2017

Citation:

Durán P, Jorquera M, Viscardi $S$,

Carrion VJ, Mora ML and Pozo MJ

(2017) Screening and Characterization

of Potentially Suppressive Soils

against Gaeumannomyces graminis

under Extensive Wheat Cropping by

Chilean Indigenous Communities.

Front. Microbiol. 8:1552.

doi: 10.3389/fmicb.2017.01552

\section{Screening and Characterization of Potentially Suppressive Soils against Gaeumannomyces graminis under Extensive Wheat Cropping by Chilean Indigenous Communities}

\author{
Paola Durán ${ }^{1,2 *}$, Milko Jorquera ${ }^{1,3}$, Sharon Viscardi ${ }^{1,2}$, Victor J. Carrion ${ }^{4}$, \\ María de la Luz Mora ${ }^{1}$ and María J. Pozo ${ }^{5 *}$
}

${ }^{1}$ Scientific and Technological Bioresource Nucleus, Universidad de La Frontera, Temuco, Chile, ${ }^{2}$ Biocontrol Research Laboratory, Universidad de La Frontera, Temuco, Chile, ${ }^{3}$ Applied Microbial Ecology Laboratory, Department of Chemical Sciences and Natural Resources, Universidad de La Frontera, Temuco, Chile, ${ }^{4}$ Netherlands Institute of Ecology, (NIOO-KNAW), Wageningen, Netherlands, ${ }^{5}$ Department of Soil Microbiology and Symbiotic Systems, Estación Experimental del Zaidín (CSIC), Granada, Spain

Wheat production around the world is severely compromised by the occurrence of "take-all" disease, which is caused by the soil-borne pathogen Gaeumannomyces graminis var. tritici (Ggt). In this context, suppressive soils are those environments in which plants comparatively suffer less soil-borne pathogen diseases than expected, owing to native soil microorganism activities. In southern Chile, where $85 \%$ of the national cereal production takes place, several studies have suggested the existence of suppressive soils under extensive wheat cropping. Thus, this study aimed to screen Ggt-suppressive soil occurrence in 16 locations managed by indigenous "Mapuche" communities, using extensive wheat cropping for more than 10 years. Ggt growth inhibition in vitro screenings allowed the identification of nine putative suppressive soils. Six of these soils, including Andisols and Ultisols, were confirmed to be suppressive, since they reduced take-all disease in wheat plants growing under greenhouse conditions. Suppressiveness was lost upon soil sterilization, and recovered by adding $1 \%$ of the natural soil, hence confirming that suppressiveness was closely associated to the soil microbiome community composition. Our results demonstrate that long-term extensive wheat cropping, established by small Mapuche communities, can generate suppressive soils that can be used as effective microorganism sources for take-all disease biocontrol. Accordingly, suppressive soil identification and characterization are key steps for the development of environmentally-friendly and efficient biotechnological applications for soil-borne disease control.

Keywords: Gaeumannomyces graminis, Mapuche, microbial communities, suppressive soils, Triticum aestivum, take-all disease, biocontrol 


\section{INTRODUCTION}

Currently, the main concerns in modern agriculture are those associated with the effect of climate change on biotic and abiotic parameters in arable soils, and their impact on crop yields and food supply at global level (Soussana et al., 2010). In this context, several authors have pointed out an increase of soil-borne disease incidence in winter cereals as a consequence of climate change (French et al., 2009; Manici et al., 2014). Similarly, these studies have also described that climate change may contribute to certain soil-borne pathogen migration toward niches or regions previously uncolonized by these pathogens (French et al., 2009).

The southern region of Chile produces around $85 \%$ of cereals, where $40 \%$ is wheat (Triticum aestivum L.; ODEPA, 2016). However, wheat production is frequently reduced by the incidence of "take-all" disease, which is caused by the soil-borne pathogen Gaeumannomyces graminis var tritici (Ggt; Andrade et al., 2011), causing the highest wheat crop losses in Chile (Moya-Elizondo et al., 2015). Soil-borne pathogen incidence in cereal cropping is difficult to control due to their natural persistence in soils and the inefficiency of chemical controls (De Coninck et al., 2015); thus, biological control becomes a very promising alternative to prevent soil diseases. The incidence of take-all disease outbreak is favored under particular soil conditions, called "conducive" soils (Chng et al., 2015). In contrast, "suppressive" soils occur as a natural phenomena, preventing soil-borne pathogen establishment or reducing disease incidence (Jara et al., 2011) even in the presence of a susceptible host plant and favorable soil or climate conditions. In this context, several studies have shown that native soil microorganism activity can be pivotal in Ggt disease suppression (Weller et al., 2002; Cook, 2003; Mendes et al., 2011, 2013). Ggt (and other soil-borne pathogens) suppressive soils have been reported and characterized around the world (Bull et al., 1991; Bithell et al., 2012; Chng et al., 2013).

In the twentieth century, agrarian policies resulted in the establishment of numerous small farmers practicing extensive agriculture in southern Chile, particularly in the "Region de La Araucania" ( $38^{\circ} 54^{\prime} 00^{\prime \prime} \mathrm{S} ; 72^{\circ} 40^{\prime} 00^{\prime \prime} \mathrm{S}$ ) (Clapp, 1998). Most farmers belong to the "Mapuche" ethnic group, which represents $50 \%$ of the total population in La Araucania. The Mapuche community is characterized by the use of ancestral agronomic techniques to produce their own agricultural products without the application of chemicals such as, commercial fertilizers and pesticides. The extensive Mapuche agriculture is mainly directed to family group subsistence. Under this scenario, we hypothesize that this long-term land-use could represent a natural and effective source of suppressive soils against soil-borne pathogen diseases. Thus, suppressive soils may also be relevant in the context of alterations related to soil-borne pathogen incidence and migration that have been predicted by climate change, and the deleterious effect on intensive agro-chemical product use in arable soils (Meza and Silva, 2009; Neuenschwander, 2010). In fact, Andrade et al. (2011) detected five Ggt-suppressive soils located in La Araucania with a long history of monoculture and natural pasture. Similarly, Arismendi et al. (2012) reported the presence of Pseudomonas fluorescens strains, which are able to produce 2, 4-DAPG, a known biocontrol compound involved in soil Ggt suppression (Mavrodi et al., 2012; Weller et al., 2012), in 13 soils from La Araucania and Los Lagos regions. Moreover, we have recently isolated and characterized four endophytic bacteria from wheat plants in this area (Acinetobacter sp. E6.2, Bacillus sp. E8.1, Bacillus sp. E5 and Klebsiella sp. E1), which are able to inhibit Ggt mycelia growth in vitro, promote plant growth, and diminish take-all disease incidence under greenhouse experiments (Durán et al., 2014). Although most studies on Ggt suppression have focussed on bacteria, there are some reports showing that some fungal strains can also reduce Ggt incidence (Macia-Vicente et al., 2008). These examples illustrate the great potential of native microorganisms as soil inoculants able to increase plant growth and prevent soil-borne pathogen disease incidence in cereal cropping. Despite of this potential, studies focusing on Ggt-suppressive soils occurrence, and their characterization, are still very limited.

The main objective of our study was to screen Ggtsuppressive soils in 16 locations managed by indigenous Mapuche communities from La Araucania, southern Chile, where extensive wheat cropping was applied for more than 10 years. Soil chemical properties and microbial community composition were characterized. Furthermore, soils were categorized as Ggt suppressive or conducive based on their potential for pathogen inhibition in vitro, and their efficacy in controlling take-all disease under greenhouse conditions.

\section{MATERIALS AND METHODS}

\section{Soil Sampling}

In southern Chile, acidic volcanic soils (Andisols and Ultisols) are the predominant soil types supporting the bulk of agricultural and forestry production. Andisols include modern and recent ash deposits, and Ultisols correspond to ancient deposits (Andrade et al., 2011). Soil samples were collected from extensive wheat cropping areas managed by Mapuche communities in 16 locations from La Araucania (Figure 1A; Table 1). Nine samples (number 3, 4, 5, 7, 10, 12, 13, 14, 15, and 16) were taken from soils with a long rotation history between wheat monoculture and natural pasture for more than 10 years, and six samples (number 2, 6, 8, 9, 11, and 12) were taken from soils with wheat monoculture including oat rotation. An additional sample number 1 was taken from a Ggt-conducive soil with wheat, including clover rotation, and used as positive control. Parent material from soils 1 to 10 was classified as Andisol, whereas 11-16 were classified as Ultisols.

Samples were collected from rhizosphere and bulk soil at 0-20 $\mathrm{cm}$ depth, and then stored in a cold room at $5^{\circ} \mathrm{C}$ until usage. Soil sample chemical properties were determined as follow. Briefly, available $\mathrm{P}\left(\mathrm{P}_{\text {Olsen }}\right)$ was extracted by using $0.5 \mathrm{M} \mathrm{Na}$-bicarbonate and analyzed by using the molybdate method (Murphy and Riley, 1962). Organic matter contents were estimated by wet digestion (Walkley and Black, 1934). Soil pH was measured in 1:2.5 soil/deionized water suspensions. Exchangeable potassium $\left(\mathrm{K}^{+}\right)$, calcium $\left(\mathrm{Ca}^{2+}\right)$, magnesium $\left(\mathrm{Mg}^{2+}\right)$, and sodium $\left(\mathrm{Na}^{+}\right)$were extracted with $1 \mathrm{M}$ ammonium acetate $\left(\mathrm{CH}_{3} \mathrm{COONH}_{4}\right)$ at $\mathrm{pH}$ 7.0 and analyzed by flame atomic adsorption spectrophotometry 


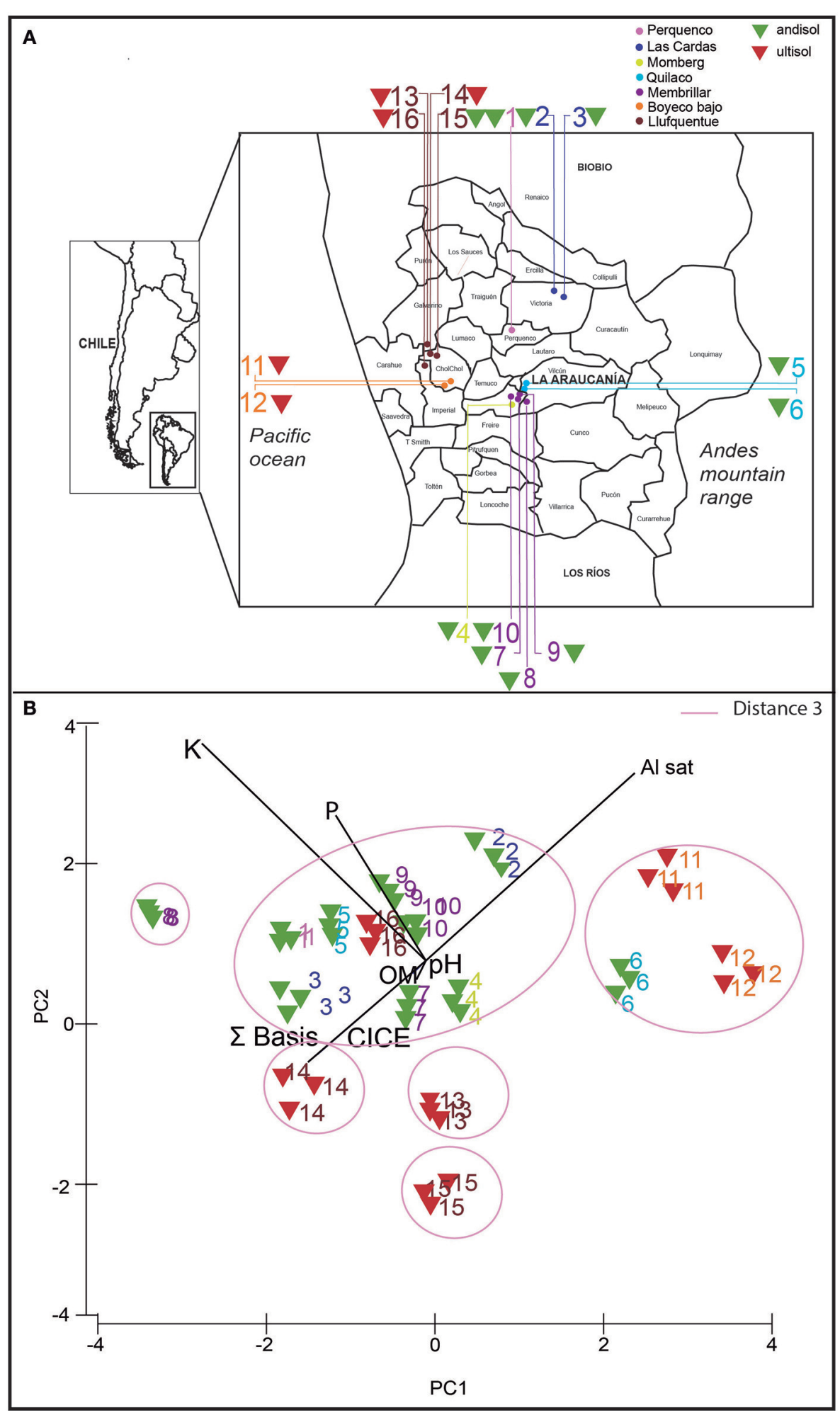

FIGURE 1 | Sampling locations (A) and principal component analysis (PCA) analysis (B) based on chemical properties of 16 rhizosphere soils used in this study. Triangle colors indicate type of soil: andisol (green) and ultisol (red). 
TABLE 1 | Sample locations and cropping history of soils used in this study.

\begin{tabular}{|c|c|c|c|c|}
\hline Soil & $\begin{array}{l}\text { Parent } \\
\text { material }\end{array}$ & Location & $\begin{array}{c}\text { GPS } \\
\text { coordinates }\end{array}$ & Cropping history \\
\hline 1 & Andisol & Perquenco & $\begin{array}{l}38^{\circ} 22^{\prime} 25.8^{\prime \prime} \mathrm{S} \\
72^{\circ} 23^{\prime} 07.5^{\prime \prime} \mathrm{W}\end{array}$ & Conducive soil (control) \\
\hline 2 & Andisol & Las Cardas-1 & $\begin{array}{l}38^{\circ} 19^{\prime} 09.3^{\prime \prime} \mathrm{S} \\
72^{\circ} 17^{\prime} 03.9^{\prime \prime} \mathrm{W}\end{array}$ & $\begin{array}{l}\text { Wheat- triticale- oat (more } \\
\text { than } 10 \text { years) }\end{array}$ \\
\hline 3 & Andisol & Las Cardas-2 & $\begin{array}{l}38^{\circ} 19^{\prime} 32.7^{\prime \prime} \mathrm{S} \\
72^{\circ} 17^{\prime} 18.6^{\prime \prime} \mathrm{W}\end{array}$ & $\begin{array}{l}\text { Wheat (10 years)- natural } \\
\text { pasture (10 years)-wheat }\end{array}$ \\
\hline 4 & Andisol & Momberg & $\begin{array}{l}38^{\circ} 50^{\prime} 30.5^{\prime \prime} \mathrm{S} \\
72^{\circ} 32^{\prime} 21.4^{\prime \prime} \mathrm{W}\end{array}$ & $\begin{array}{l}\text { Natural pasture ( } 10 \\
\text { years)-clover- wheat-wheat }\end{array}$ \\
\hline 5 & Andisol & Quilaco-1 & $\begin{array}{l}38^{\circ} 43^{\prime} 25.9^{\prime \prime} \mathrm{S} \\
72^{\circ} 27^{\prime} 19.2^{\prime \prime} \mathrm{W}\end{array}$ & $\begin{array}{l}\text { Natural pasture (10 } \\
\text { years)-wheat }\end{array}$ \\
\hline 6 & Andisol & Quilaco-2 & $\begin{array}{l}38^{\circ} 43^{\prime} 35.7^{\prime \prime} \mathrm{S} \\
72^{\circ} 27^{\prime} 34.5^{\prime \prime} \mathrm{W}\end{array}$ & Clover (5 years)-oat- wheat \\
\hline 7 & Andisol & Membrillar-1 & $\begin{array}{l}38^{\circ} 45^{\prime} 01.6^{\prime \prime} \mathrm{S} \\
72^{\circ} 28^{\prime} 28.4^{\prime \prime} \mathrm{W}\end{array}$ & $\begin{array}{l}\text { Natural pasture-wheat (15 } \\
\text { years) }\end{array}$ \\
\hline 8 & Andisol & Membrillar-2 & $\begin{array}{l}38^{\circ} 45^{\prime} 15.1^{\prime \prime} \mathrm{S} \\
72^{\circ} 26^{\prime} 63.2^{\prime \prime} \mathrm{W}\end{array}$ & Oat-wheat-wheat (30 years) \\
\hline 9 & Andisol & Membrillar-3 & $\begin{array}{l}38^{\circ} 44^{\prime} 57.9^{\prime \prime} \mathrm{S} \\
72^{\circ} 28^{\prime} 58.7^{\prime \prime} \mathrm{W}\end{array}$ & Wheat-oat+natural pasture \\
\hline 10 & Andisol & Membrillar-4 & $\begin{array}{l}38^{\circ} 44^{\prime} 52.8^{\prime \prime} \mathrm{S} \\
72^{\circ} 29^{\prime} 21.3^{\prime \prime} \mathrm{W}\end{array}$ & $\begin{array}{l}\text { Natural pasture (10 years)- } \\
\text { wheat ( } 2 \text { years) }\end{array}$ \\
\hline 11 & Ultisol & Boyeco bajo-1 & $\begin{array}{l}38^{\circ} 39^{\prime} 00.4^{\prime \prime} \mathrm{S} \\
72^{\circ} 41^{\prime} 41.7^{\prime \prime} \mathrm{W}\end{array}$ & $\begin{array}{l}\text { Wheat-oat-wheat-wheat } \\
\text { (more than } 20 \text { years) }\end{array}$ \\
\hline 12 & Ultisol & Boyeco bajo-2 & $\begin{array}{l}38^{\circ} 39^{\prime} 48.8^{\prime \prime} \mathrm{S} \\
72^{\circ} 42^{\prime} 08.8^{\prime \prime} \mathrm{W}\end{array}$ & $\begin{array}{l}\text { Natural pasture (10 years)- } \\
\text { wheat- oat- wheat }\end{array}$ \\
\hline 13 & Ultisol & Llufquentue-1 & $\begin{array}{l}38^{\circ} 25^{\prime} 44.5^{\prime \prime} \mathrm{S} \\
72^{\circ} 46^{\prime} 12.3^{\prime \prime} \mathrm{W}\end{array}$ & $\begin{array}{l}\text { Wheat- wheat- natural } \\
\text { pasture- wheat (more than } \\
10 \text { years) }\end{array}$ \\
\hline 14 & Ultisol & Llufquentue-2 & $\begin{array}{l}38^{\circ} 28^{\prime} 55.1^{\prime \prime} \mathrm{S} \\
72^{\circ} 43^{\prime} 25.6^{\prime \prime} \mathrm{W}\end{array}$ & Wheat (more than 20 years) \\
\hline 15 & Ultisol & Llufquentue-3 & $\begin{array}{l}38^{\circ} 28^{\prime} 53.1^{\prime \prime} \mathrm{S} \\
72^{\circ} 43^{\prime} 27.6^{\prime \prime} \mathrm{W}\end{array}$ & Wheat (more than 20 years) \\
\hline 16 & Ultisol & Llufquentue-4 & $\begin{array}{l}38^{\circ} 29^{\prime} 38.2^{\prime \prime} \mathrm{S} \\
72^{\circ} 45^{\prime} 26.2^{\prime \prime} \mathrm{W}\end{array}$ & $\begin{array}{l}\text { Natural pasture (10 years)- } \\
\text { wheat- wheat }\end{array}$ \\
\hline
\end{tabular}

(FAAS) (Warncke and Brown, 1998). Exchangeable aluminum $\left(\mathrm{Al}^{3+}\right)$ was extracted with $1 \mathrm{M} \mathrm{KCl}$ and analyzed by FAAS (Bertsch and Bloom, 1996). All samples analyses were made in triplicate. To group and determine significant differences between samples based on their chemical properties, data were imported into the PRIMER 7 software (PRIMER-E Ltd, Ivybridge, UK), transformed and normalized using square-root followed by a $\log$ (Xp1) transformations (Lee et al., 2012). Then, a distance matrix was generated based on Euclidean distances and samples were grouped by hierarchical clustering (group average), and then visualized by principal component analysis (PCA).

\section{Bacterial Community Composition and Ggt Detection in Soil Samples}

Bacterial community compositions in rhizosphere and bulk soil samples were examined by denaturing gradient gel electrophoresis (DGGE), according to Iwamoto et al. (2000). Total genomic DNA was extracted from 0.5 to $1 \mathrm{~g}$ of soil samples using the PowerSoil ${ }^{\circledR}$ DNA Isolation Kit (Mo-Bio
Laboratories, Carlsbad, CA, USA), according to manufacturer's instructions. The 16S rRNA gene fragments were amplified by touchdown PCR, using EUBf933-GC/EUBr1387 primer set (Iwamoto et al., 2000). DGGE analysis was performed using a DCode system (Bio-Rad Laboratories, Inc., USA). The PCR product $(20 \mu \mathrm{L})$ was loaded onto a $6 \%(\mathrm{v} / \mathrm{v})$ polyacrylamide gel with a $40-70 \%$ gradient (urea and formamide). Electrophoresis was run for $12 \mathrm{~h}$ at $100 \mathrm{~V}$. Banding profiles were visualized by staining the gel 1:10.000 (v/v) with SYBR Gold (Molecular Probes, Invitrogen Co., USA) for $30 \mathrm{~min}$, followed by image capture using GelDoc-It ${ }^{\text {TS2 }}$ Imager (UVP, Upland, CA, USA). DGGE banding profile clustering, using a dendrogram, was also carried out by using Phoretix 1D analysis software (TotalLab Ltd., UK). The correlation between bacterial communities (biological parameters) and chemical soil properties (ecological parameters) was visualized by non-metric multidimensional scaling (MDS) analysis using Primer 7 + Permanova software (Primer-E Ltd., Ivybridge, UK) (Clarke, 1993). The in silico analysis was also used to estimate the bacterial diversity by richness (S), ShannonWiener, and dominance by Simpson Index (D), represented by $1-D$ or 1- $\lambda$ (Sagar and Sharma, 2012).

Ggt occurrence in soil samples: DNA extracts from soil samples were subjected to PCR using the primer set NS5 ( $5^{\prime}$-AAC TTA AAG GAA TTG ACG GAA G-3') and GGT-RP ( $5^{\prime}$-TGC AAT GGC TTC GTG AA- $3^{\prime}$ ) designed by Fouly and Wilkinson (2000) specifically for Ggt. The PCR conditions were as follow: an initial denaturation at $93^{\circ} \mathrm{C}$ for $3 \mathrm{~min}$, followed for $93^{\circ} \mathrm{C}$ for 1 min, $52^{\circ} \mathrm{C}$ for $1 \mathrm{~min}$, and $72^{\circ} \mathrm{C}$ for $1 \mathrm{~min}$ to 35 cycles, and finally with $72^{\circ} \mathrm{C}$ for $5 \mathrm{~min}$. All soil samples were tested in triplicate, and pure G. graminis var tritici (Andrade et al., 2011) and Aspergillus niger DNA (code CCT-UFRO 15.62), obtained from La Frontera University Type Strain Culture Collection (http://ccct.ufro.cl/), were used as positive and negative controls, respectively. The presence of Ggt in soil samples showing positive Ggt reaction was also confirmed by the presence of take-all disease symptoms, chlorosis, and blackening roots in wheat seedlings in the pot assays.

\section{Putative Ggt-Suppressive Soil Screening}

Putative Ggt-suppressive soil screening was performed by two in vitro inhibition tests using rhizosphere soil samples as follows:

\section{In vitro Inhibition Test on Solid Media}

A first screening was carried out in order to evaluate rhizosphere soil capability of inhibiting Ggt growth on agar plates (Supplementary Figure 1A). Briefly, the Ggt inoculum was produced by growing the fungus on potato dextrose agar (PDA) medium at $25^{\circ} \mathrm{C}$ for 1 week. Agar disks (4-mm diameter) containing Ggt were aseptically incised and transferred to the center of agar plates containing fresh Luria Bertani (LB) and PDA medium (proportion 1:1). A hole of $10 \mathrm{~mm}$ was performed in the agar medium at a distance of $3 \mathrm{~cm}$ from Ggt inoculum, and 0.05 $\mathrm{g}$ of rhizosphere soil were placed in the agar hole. Ggt mycelia growth was registered at 3,5 , and 7 days of incubation at $25^{\circ} \mathrm{C}$ in the darkness, as described by Liu et al. (2011). A fraction of all soil samples was sterilized and samples included in the agar as negative controls. All tests were carried out in triplicate. 


\section{In vitro Inhibition Test in Aqueous Soil Extracts}

Because some soils contained elevated loads of microorganisms affecting fungal measurements on agar medium (categorized as un-determined in the in vitro test described in Section In vitro Inhibition Test on Solid Media), a second assay was performed in tubes with rhizosphere soil extracts (Supplementary Figure 1B). Briefly, $1 \mathrm{~g}$ of rhizosphere soil sample was suspended in $9 \mathrm{ml}$ of sterile phosphate buffer saline (PBS; $\mathrm{pH} 7.4$ ), and sonicated at $60 \%$ amplitude for $30 \mathrm{~s}$. Then, $1 \mathrm{~mL}$ of supernatant was added to an eppendorf, and then inoculated with $1 \%$ Ggt inoculum. Soil extract tubes were incubated at room temperature for 3, 5, and 7 days, and fungal growth was estimated by quantification of fungal biomass by crystal violet (CV) staining as follows. After incubation, soil extract samples were washed with distilled water and fixed with $500 \mu \mathrm{l}$ methanol for $15 \mathrm{~min}$ at room temperature. Later, they were centrifuged at 13,000 $\mathrm{rpm} \times 1 \mathrm{~min}$, supernatants were discarded, and tubes were air-dried; $400 \mu \mathrm{l}$ of CV was added to each tube and incubated for $5 \mathrm{~min}$. Tubes were washed three times with distilled water. Finally, $400 \mu \mathrm{l}$ of acetic acid (33\% v/v) were added and kept in the tubes for $5 \mathrm{~min}$. The absorbance of the obtained solution was determined in triplicate in a multi-plate reader at $590 \mathrm{~nm}$ (Silva et al., 2009, Supplementary Figure 1B).

Nine putative suppressive soils from the inhibition tests, in both agar plates and soil extract tubes, were used for the greenhouse assay, using soil 1 as Ggt-conducivepositive control.

\section{Take-All Disease Suppression Assay in Greenhouse Inoculum Preparation}

The characterization of the pathogen as Ggt was done based on the sequencing of ribosomal internal transcribed spacer 2 region (ITS2). ITS2 was amplified by touchdown polymerase chain reaction (PCR) with primer sets fITS9 (5'-GAACGCAG CRAAIIGYG-3') and ITS4 (5-'TCCTCCGCTTATTGATATGC$3^{\prime}$ ), using the following conditions: an initial denaturation at $95^{\circ} \mathrm{C}$ for $3 \mathrm{~min}$, followed by 25 cycles-each at $95^{\circ} \mathrm{C}$ for $30 \mathrm{~s}$, with an annealing step with a $0.5^{\circ} \mathrm{C}$ decrease-each cycle from $65^{\circ} \mathrm{C}$ to $52.5^{\circ} \mathrm{C}$, and extension at $72^{\circ} \mathrm{C}$ for $30 \mathrm{~s}$. Twenty-five additional cycles were then carried out at $95^{\circ} \mathrm{C}$ denaturation for $30 \mathrm{sec}, 55^{\circ} \mathrm{C}$ annealing, primer extension at $72^{\circ} \mathrm{C}$ for $30 \mathrm{~s}$, and a final extension step of $7 \mathrm{~min}$ at $72^{\circ} \mathrm{C}$. The PCR products were purified and sequenced by Austral-Omics (Universidad Austral of Valdivia-Chile). The sequence was compared with those in the GenBank database, fungal identity was confirmed (99\%), and then deposited under accession no. KY689233.

The Ggt inoculum was prepared as follows: oat kernels were soaked in water for $24 \mathrm{~h}$ and sterilized for 3 consecutive days. Then, Ggt pathogenic isolate discs were grown on PDA for 7 days, put on the sterile oat, and maintained at room temperature for 20 days. Colonized oat kernels were blended, sieved to a particle size of $0.5-1.0 \mathrm{~mm}$, and stored at $5^{\circ} \mathrm{C}$ until usage (Andrade et al., 2011).

\section{Greenhouse Assay}

Nine putative suppressive soils (number 2, 3, 4, 6, 11, 13, 14, 15, and 16), selected according to results obtained in the in vitro tests (Section Putative Ggt-Suppressive Soil Screening), were tested in their ability to suppress take-all disease in planta under greenhouse conditions. Plastic containers enclosing $200 \mathrm{~g}$ of soil were used in quintuplicate. Wheat seeds Otto cv were surface sterilized ( $15 \%$ ethanol plus $1 \%$ sodium hypochlorite for $2 \mathrm{~min}$ ) and 5 seeds were used for each treatment. Plants were watered every 3 days, and Taylor and Foyd nutrient solution (Taylor and Foyd, 1985) was applied each 15 days.

The experimental design consisted in sterile (heat-treated) rhizosphere soil to determine disease level incidence, discarding, or diminishing the effect of soil microorganisms; untreated, air-dried soil (natural) to determine the effect of soil native microorganisms; and, sterile soil $+1 \%$ untreated, natural soil (ster $+1 \%$ nat) to assess suppression transferability to sterile soils. Suppression transferability has been shown to occur when natural soils are added in as low as $1 \%(\mathrm{v}: \mathrm{v})$ to non-suppressive soils, as reported earlier (Shipton et al., 1973; Andrade et al., 1994). Ggt inocula were applied at $0.1 \%$ in relation to soil weight ( $2 \mathrm{~g})$, and all treatments were also performed in soil without Ggt inocula as controls. After 40 days, plants were carefully removed from the soil, weighted and the root blackening percentage was determined.

\section{Ggt Presence in Plant Tissues}

The Ggt presence was evaluated in roots of PCR infected and non-infected plants. Roots were individually assessed for infection and root blackening percentage was evaluated against a white background. Shoots were carefully separated from the roots, placed into individual paper envelopes, and dried at $70^{\circ} \mathrm{C}$ for $72 \mathrm{~h}$, to obtain shoot dry weight. In order to confirm Ggt infection, total DNA from wheat infected tissues was extracted with soil DNA Isolation Kit (Ultraclean, Mo-Bio Laboratories) according to manufacturer's instructions. Specific Ggt DNA fragments were amplified by using NS5 and GGT-RP primer sets, as described in Section Bacterial Community Composition and Ggt Detection in Soil Samples. Pure DNA extracts from Ggt and A. niger collection strains were used as positive and negative control, respectively.

\section{Presence of 2,4-Diacetylphloroglucinol-Producing Bacteria}

The presence of 2,4-DAPG-producing bacteria was also evaluated by PCR. Total DNA from rhizosphere soil was extracted with soil DNA Isolation Kit (Ultraclean, Mo-Bio Laboratories) according to manufacturer's instructions. Specific primer sets B2BF ( $5^{\prime} \mathrm{ACC}$ CAC CGC AGC ATC GTT TAT GAG C-3') and BPR4 (5'CCG CCG GTA TGG AAG ATG AAA AAG TC-3'), which target the phlD gene (encoding a polyketide synthase that synthesizes monoacetylphloroglucinol, the precursor to 2,4-DAPG that is essential for the phloroglucinol biosynthesis) were used in the PCR reaction (Gardener et al., 2001). PCR conditions were: an initial denaturation at $95^{\circ} \mathrm{C}$ for $3 \mathrm{~min}$, followed by 35 cycles each at $95^{\circ} \mathrm{C}$ denaturation for $1 \mathrm{~min}, 60^{\circ}$ annealing for $1 \mathrm{~min}, 72^{\circ} \mathrm{C}$ extension for $1 \mathrm{~min}$, and final extension step for $10^{\prime}$ at $72^{\circ} \mathrm{C}$. Pure DNA extracts from Pseudomonas spp. (SA 32A) and Enterobacter spp. (RJAL6) strains were used as positive and negative controls, respectively (Mora et al., 2017). 
Bacterial Community Structure in Suppressive Soils The bacterial community composition in the rhizosphere suppressive soils from the greenhouse assay was examined by DGGE as described in Section Bacterial Community Composition and Ggt Detection in Soil Samples. The similarity between bacterial communities was visualized by non-metric multidimensional scaling analysis (MDS), using Primer 7 software (Primer-E Ltd., Ivybridge, UK), which showed a BrayCurtis similarity index higher than $50 \%$ and 0.14 stress values (Clarke, 1993).

\section{Statistical Analyses}

Data normality was analyzed according to Kolmogorov's test. Data obtained in Section In vitro Inhibition Test on Solid Media (in vitro plate assay) were analyzed by a one-way analysis of variance (ANOVA) and compared by Tukey test, using SPSS software (SPSS, Inc.). Comparisons between inoculated and noninoculated samples from screening 2 were made, and Student $t$-test was used for related samples with $95 \%$ confidence interval. For the greenhouse assay multivariate analysis of variance (MANOVA) and comparisons were carried out for each set with Tukey's test by SPSS software (SPSS, Inc.). Values were given as means \pm standard errors. Differences were considered significant when the $P$ value was lower than or equal to 0.01 . The microbial diversity analysis was described above.

\section{RESULTS}

\section{Collected Soils Grouped According to their Chemical Composition}

In order to determine the chemical composition of the collected soils, chemical analyses were performed using triplicate samples of each soil. The main chemical parameters that were measured are shown in Table 2. In general, soil samples showed values of available $\mathrm{P}$ from 5.6 (soil 13) to $60 \mathrm{mg} \mathrm{kg}^{-1}$ (Soils 1 and 4). The $\mathrm{pH}$ ranged from 5.0 (soils 11 and 12) to 6.4 (soil 15). The OM contents varied from $6 \%$ (soil 14) to $15 \%$ (soils 6,7 , and 15). The higher values of $\mathrm{S}$ bases and $\mathrm{Al}$ saturation were observed in soil $15\left(29.4 \mathrm{cmol}_{(+)} \mathrm{kg}^{-1}\right)$ and soil $11(14 \%)$, respectively; whereas lower values were observed in soil $6(4.7$ $\left.\mathrm{cmol}_{(+)} \mathrm{kg}^{-1}\right)$ and soil $15\left(0 \mathrm{cmol}_{(+)} \mathrm{kg}^{-1}\right)$. In addition, the PCA analysis showed that soils were grouped based on their chemical composition and soil classification, Andisol and Ultisol (Figure 1B). Several soil groups were formed, soils collected from Perquenco, Las Cardas, Momberg, Quilaco, Membrillar, and Lufquentue clustered together (soils 1, 2, 3, 4, 5, 7, 9, 10, and 16, respectively), soils from Quilaco (6) and Boyeco (11 and 12), and three soils collected from Lufquentue (soils 13, 14, and 15) and Quilaco (soil 8) did not cluster with any other group.

\section{Bacterial Community Composition is Related to Chemical Soil Composition and Differs in Bulk and Rhizosphere Soils in Terms of Dominance and Diversity}

Rhizosphere community composition is highly related to soil classification as revealed by MDS, in which microbiology and soil chemical/environmental properties were analyzed (Figure 2A). Samples from Andisol and Ultisol were notably different from each other, with 55\% similarity. According to the Spearman correlation, Ultisol soils were more significantly related with chemical parameters than Andisol soils $\left(r^{2}=0.90\right.$ and $r^{2}=0.59$, respectively, Table 3). Bulk soils were also separated according to the chemical soil composition, but this difference was not significant, and all samples were grouped at 55\% (Figure 2B). In

TABLE 2 | Average values for some chemical properties of rhizosphere soils used in this study.

\begin{tabular}{|c|c|c|c|c|c|c|c|}
\hline Soil & $P\left(\mathrm{mg} \mathrm{kg}^{-1}\right)$ & $\mathrm{K}\left(\mathrm{cmol}+\mathrm{kg}^{-1}\right)$ & $\mathrm{pH}\left(\mathrm{H}_{2} \mathrm{O}\right)$ & OM (\%) & Al sat $^{\dagger}(\%)$ & CICE $\left(\mathrm{cmol}+\mathrm{kg}^{-1}\right)$ & $\Sigma$ basis $\left(\mathrm{cmol}_{(+)} \mathrm{kg}^{-1}\right)$ \\
\hline 1 & $60.3 \pm 0.8^{a *}$ & $2.8 \pm 0.1^{b c}$ & $5.9 \pm 0.1^{b}$ & $12.2 \pm 0.1^{d}$ & $0.6 \pm 0.0^{h i j}$ & $16.9 \pm 0.0^{e}$ & $16.9 \pm 0.0^{e}$ \\
\hline 2 & $41.5 \pm 0.9^{\mathrm{cd}}$ & $1.2 \pm 0.0^{f}$ & $5.3 \pm 0.0^{f}$ & $10.9 \pm 0.2^{\mathrm{e}}$ & $9.9 \pm 0.1^{c}$ & $11.0 \pm 0.1^{h}$ & $9.9 \pm 0.1^{i}$ \\
\hline 3 & $22.2 \pm 0.6^{h}$ & $3.0 \pm 0.1^{b}$ & $5.8 \pm 0.0^{\mathrm{bc}}$ & $10.4 \pm 0.3^{e f}$ & $0.9 \pm 0.1^{f g h}$ & $18.5 \pm 0.1^{d}$ & $18.3 \pm 0.1^{d}$ \\
\hline 4 & $59.8 \pm 0.2^{\mathrm{a}}$ & $0.6 \pm 0.0^{h i}$ & $5.7 \pm 0.0^{\mathrm{bc}}$ & $15.1 \pm 0.1^{a b}$ & $1.1 \pm 0.0^{f g}$ & $9.4 \pm 0.0^{i}$ & $9.3 \pm 0.0^{i}$ \\
\hline 5 & $40.1 \pm 1.0^{d}$ & $2.6 \pm 0.1^{c}$ & $5.7 \pm 0.1^{b c}$ & $15.3 \pm 0.3^{a}$ & $0.7 \pm 0.0^{f g h}$ & $13.9 \pm 0.09$ & $13.8 \pm 0.09$ \\
\hline 6 & $22.2 \pm 0.1^{\mathrm{h}}$ & $0.4 \pm 0.0^{\mathrm{ij}}$ & $5.4 \pm 0.1^{\text {def }}$ & $15.9 \pm 0.2^{a}$ & $3.3 \pm 0.1^{d}$ & $4.8 \pm 0.1^{\mathrm{jk}}$ & $4.7 \pm 0.1^{j}$ \\
\hline 7 & $33.1 \pm 0.1^{f}$ & $1.2 \pm 0.0^{f}$ & $5.7 \pm 0.1^{\mathrm{bc}}$ & $15.4 \pm 0.2^{\mathrm{a}}$ & $0.6 \pm 0.1^{g h i}$ & $10.9 \pm 0.1^{\mathrm{h}}$ & $10.8 \pm 0.1^{h}$ \\
\hline 8 & $53.4 \pm 0.1^{b}$ & $9.2 \pm 0.1^{a}$ & $6.3 \pm 0.0^{a}$ & $13.9 \pm 0.2^{\mathrm{C}}$ & $0.0 \pm 0.0^{j}$ & $28.1 \pm 0.2^{b}$ & $28.1 \pm 0.2^{b}$ \\
\hline 9 & $37.5 \pm 0.2^{e}$ & $2.2 \pm 0.1^{d}$ & $5.6 \pm 0.0^{\text {cde }}$ & $10.9 \pm 0.3^{\mathrm{e}}$ & $2.3 \pm 0.0^{\mathrm{e}}$ & $11.2 \pm 0.2^{h}$ & $11.0 \pm 0.2^{h}$ \\
\hline 10 & $42.7 \pm 0.2^{c}$ & $2.1 \pm 0.1^{\mathrm{de}}$ & $5.6 \pm 0.1^{\text {cde }}$ & $14.0 \pm 0.3^{b c}$ & $1.2 \pm 0.0^{f g}$ & $9.9 \pm 0.1^{i}$ & $9.8 \pm 0.1^{i}$ \\
\hline 11 & $16.1 \pm 0.3^{i}$ & $0.8 \pm 0.0^{g h}$ & $5.0 \pm 0.0^{9}$ & $7.7 \pm 0.1^{\mathrm{g}}$ & $14.0 \pm 0.4^{a}$ & $5.8 \pm 0.1^{j}$ & $5.0 \pm 0.0^{j}$ \\
\hline 12 & $13.5 \pm 0.2^{j}$ & $0.2 \pm 0.0^{j}$ & $5.0 \pm 0.0^{9}$ & $9.6 \pm 0.1^{f}$ & $12.5 \pm 0.1^{b}$ & $6.3 \pm 0.0^{j}$ & $5.5 \pm 0.0^{j}$ \\
\hline 13 & $5.6 \pm 0.4^{k}$ & $0.9 \pm 0.0^{g h}$ & $5.6 \pm 0.0^{\mathrm{cd}}$ & $13.5 \pm 0.2^{c}$ & $0.5 \pm 0.0^{h i j}$ & $15.7 \pm 0.1^{f}$ & $15.6 \pm 0.1^{f}$ \\
\hline 14 & $30.0 \pm 0.3^{9}$ & $1.1 \pm 0.0^{f g}$ & $6.2 \pm 0.1^{a}$ & $6.1 \pm 0.3^{h}$ & $0.1 \pm 0.0^{\mathrm{ij}}$ & $24.8 \pm 0.4^{C}$ & $24.7 \pm 0.4^{C}$ \\
\hline 15 & $16.0 \pm 0.3^{i}$ & $0.3 \pm 0.0^{j}$ & $6.4 \pm 0.1^{a}$ & $15.2 \pm 0.2^{a}$ & $0.0 \pm 0.0^{j}$ & $29.4 \pm 0.3^{a}$ & $29.4 \pm 0.3^{a}$ \\
\hline 16 & $54.2 \pm 0.1^{b}$ & $1.8 \pm 0.0^{\mathrm{e}}$ & $5.3 \pm 0.1^{\text {ef }}$ & $7.9 \pm 0.3^{9}$ & $0.6 \pm 0.0^{g h i}$ & $11.6 \pm 0.1^{h}$ & $11.5 \pm 0.1^{h}$ \\
\hline
\end{tabular}

${ }^{\dagger}$ Calculated as Al/cation exchange capacity [ $\Sigma(K, \mathrm{Ca}, \mathrm{Mg}, \mathrm{Na}$, and $\left.\mathrm{Al})\right] \times 100, n=3$.

${ }^{*}$ Different letters in same column denote significant differences (Tukey's test, $P \leq 0.05$ ). 


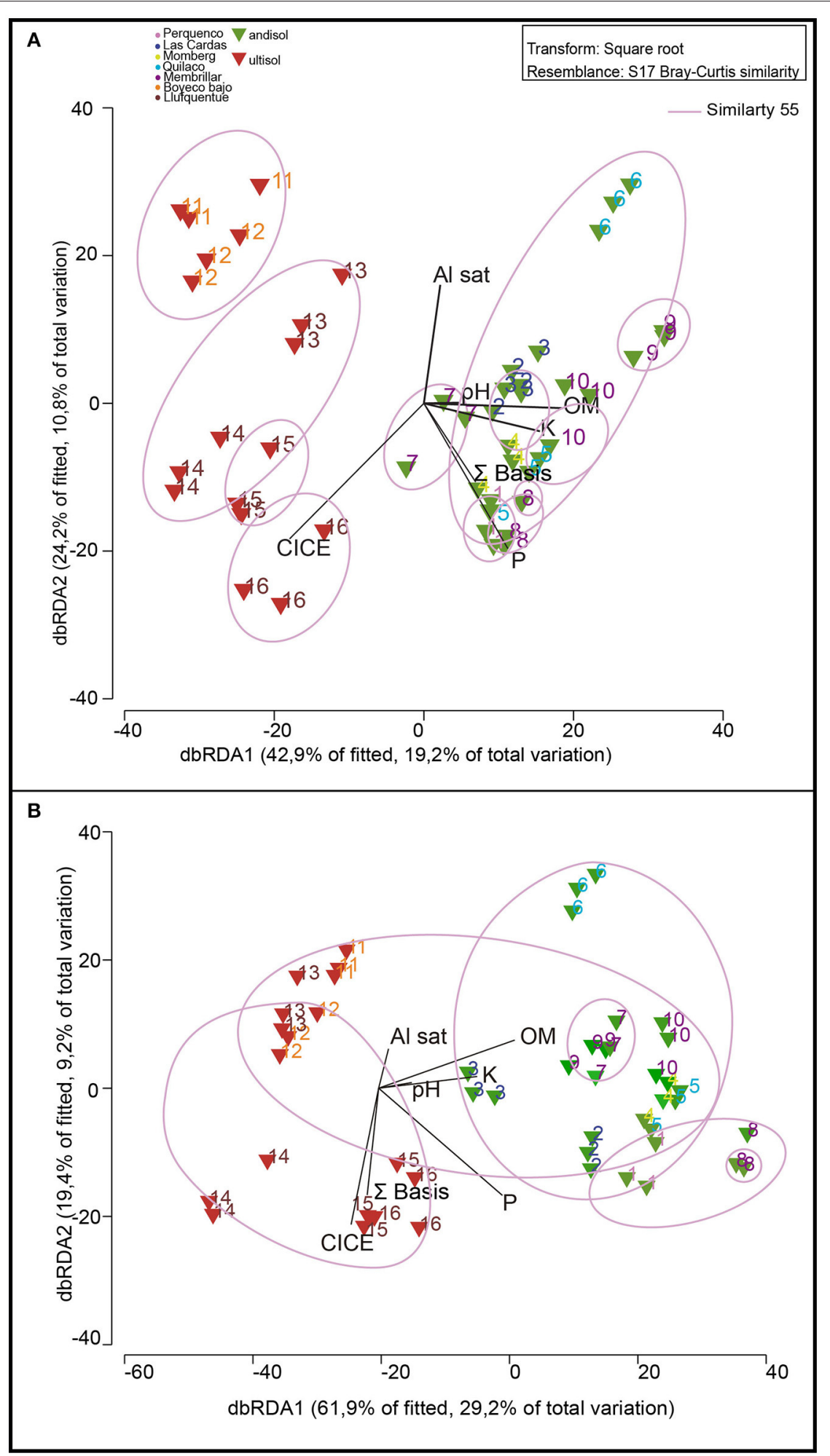

FIGURE 2 | Non-metric Multidimensional Scaling (NMDS) analysis of the 16 soils used in this study based in DGGE profiles of bacterial communities in relation with soil parameters (P, K, OM, Al sat, CICE, and $\Sigma$ basis). Color of numbers represent sector of sampling and triangle colors indicate type of soil: andisol (green) and ultisol (red). The length and position of the black lines (soil parameters) indicate correlation strength and direction of significant variables $(P<0.05)$ with the microbial community of rhizosphere (A) and bulk soil (B) 
TABLE $3 \mid R^{2}$ values and significance level for NMDS ordination and environmental variables.

\begin{tabular}{|c|c|c|c|c|c|c|}
\hline \multirow[b]{2}{*}{ Soil parameters } & \multirow[b]{2}{*}{ All samples } & \multicolumn{2}{|c|}{ Rhizosphere soil } & \multicolumn{2}{|c|}{ Bulk soil } & \multirow[b]{2}{*}{ Ultisol } \\
\hline & & Andisol & Ultisol & All samples & Andisol & \\
\hline$P\left(\mathrm{mg} \mathrm{kg}^{-1}\right)$ & $0.001^{\star \star}$ & $0.020^{*}$ & $0.001^{\star \star}$ & $0.001^{\star \star}$ & $0.003^{\star \star}$ & $0.005^{\star \star}$ \\
\hline $\mathrm{pH}\left(\mathrm{H}_{2} \mathrm{O}\right)$ & $0.027^{\star \star}$ & $0.037^{\star}$ & $0.05^{\star}$ & 0.257 & 0.513 & 0.508 \\
\hline $\mathrm{K}\left(\mathrm{mg} \mathrm{kg}^{-1}\right)$ & $0.028^{\star \star}$ & 0.09 & $0.001^{\star \star}$ & 0.128 & $0.001^{\star \star}$ & $0.001^{\star \star}$ \\
\hline $\mathrm{OM}(\%)$ & $0.003^{\star \star}$ & $0.003^{\star \star}$ & $0.001^{\star \star}$ & $0.001^{\star \star}$ & $0.014^{\star}$ & $0.016^{\star}$ \\
\hline Al saturation (\%) & $0.008^{\star \star}$ & $0.006^{\star \star}$ & $0.001^{\star \star}$ & 0.167 & 0.066 & 0.08 \\
\hline $\mathrm{CICE}\left(\mathrm{cmol}+\mathrm{kg}^{-1}\right)$ & $0.003^{\star \star}$ & $0.001^{\star \star}$ & 0.507 & 0.007 & 0.968 & 0.97 \\
\hline$\Sigma$ basis $\left(\mathrm{cmol}_{(+)} \mathrm{kg}^{-1}\right)$ & $0.001^{\star \star}$ & $0.012^{*}$ & 0.123 & 0.069 & $0.036^{\star}$ & $0.023^{*}$ \\
\hline$R^{2}$ (Spearman) & 0.45 & 0.59 & 0.90 & 0.47 & 0.83 & 0.83 \\
\hline
\end{tabular}

${ }^{\star}$ Represents statistically significant correlation $(P<0.05)$, ${ }^{* \star}$ represent statistically significant correlation $(P<0.01)$.

this sense, both Andisol and Ultisol were equally related with soil chemical parameters $\left(r^{2}=0.83\right.$, Table 3$)$.

Differences in bacterial community structures between bulk and rhizosphere soil were revealed by MDS analysis, based on DGGE banding profiles. In relation to bulk soils, the nMDS analysis revealed the existence of major groups at $40 \%$ similarity formed by rhizosphere soils indistinctly grouped, all correlated among them. In general, bulk soils were separated into two main groups formed mainly by Andisol (soil 1, 2, 3, 4, 5, 6, 7) and Ultisol soils (11, 12, 13, 14, 15, 16) (Figure 3).

Regarding the microbial diversity in bulk and rhizosphere soils (Supplementary Figure 2), in general, the Shannon index $\left(H^{\prime}\right)$ showed values $<2.0$ for bulk (except soils 5 and 6 from Quilaco) whereas it reached values $\sim 2.5$ for rhizosphere soil, indicating a lower diversity in bulk than in rhizosphere soils. A similar trend was observed in the case of species number (S). The lowest diversities $(<1.0)$ and species richness $(S)$ were observed in bulk soils from Membrillar (soils 9 and 10) whereas highest diversity values were obtained in rhizosphere soils from Quilaco (soil 5 and 6). As for bulk soils, rhizosphere soils taken from Membrillar also showed lower diversity values $(\leq 2.0)$. In contrast, less dominance values in rhizosphere soils compared with bulk soils were also observed by Simpsons (D) index represented by $1-D$, in which the lower values indicate major dominance of species. Thus, samples 9 and 10, which showed less diversity according to the Shannon index, also showed major dominance of species. Therefore, bulk soils showed lower biodiversity and major dominance compared to rhizosphere soils (Supplementary Figure 2), and we observed a direct Pearson correlation between both indexes $(P<0.01$, data not shown).

\section{Screening for Putative Ggt-Suppressive Soils}

According to the in vitro inhibition test on solid media (Figure 4A and Supplementary Figure 1A), four soils from Las Cardas (soils 2 and 3), Boyeco (soil 11), and Llufquentue (soil 16) were considered as suppressive against Ggt, since Ggt growth was significantly inhibited when compared with the positive control. However, several soils could not be properly evaluated based on this assay and were classified as undetermined. A second evaluation, using the in vitro inhibition test in aqueous soil extracts (Figure 4B and Supplementary Figure 1B) suggested the presence of nine Ggt-suppressive soils. They were collected from Las Cardas, Momberg, Quilaco, Boyeco, and Llufquentue (soils $2,3,4,6,11,13,14,15$, and 16 , respectively). In line with the assay on solid agar, this test also showed that soils collected from Membrillar (soils 7, 9, 10, and 12) were Ggt conducive. This assay also revealed the presence of other Ggt-conducive soils (soils 5 and 8), including the positive control soil 1. In summary, based on in vitro experiments, 9 soils were determined as suppressive, and 7 as conducive (Figure 4B).

\section{Suppressive Soil Greenhouse Assay Incidence of Take-All Disease}

Firstly, we aimed to establish a positive control for take all decline and soil conduciveness for our suppressive soil assays. Plants growing in soil 1 showed clear disease symptoms including leaf chlorosis and blackening root, distinctive take-all disease symptoms. We confirmed the presence and the identity of Ggt in the rhizospheric soil, extracting the total DNA and using Ggt specific primers. The PCR amplification confirmed that soil 1 was positive in terms of Ggt presence (Supplementary Figure 3). Then, to confirm the ability to suppress take-all disease in the putative nine rhizosphere soils selected through the in vitro assays (Figure 4), an assay with the pathosystem wheatGgt was performed under greenhouse conditions by growing wheat in Ggt-inoculated and non-inoculated soils. Take-all disease symptoms were evident in all inoculated soils, except in soil 11 (data not shown). The origin of the symptoms was confirmed by Ggt DNA amplification with Ggt specific primers of infected plants; the amplification band was present in all Ggt-inoculated rootswhereas it was absent in the non-inoculated plants (Supplementary Figure 4). In order to determine whether Ggt suppressiveness was due to microbial community or to soil physico-chemical characteristics, sterilization by heat treatment of the soils was performed. The plants grown in the greenhouse on heat-treated sterilized soils showed higher disease symptoms than in the corresponding natural soils (Figure 5): the percentage of blackening root for plants growing in sterile soils ranged between 10 and 40\%, while only between 3 and 10\% for natural 


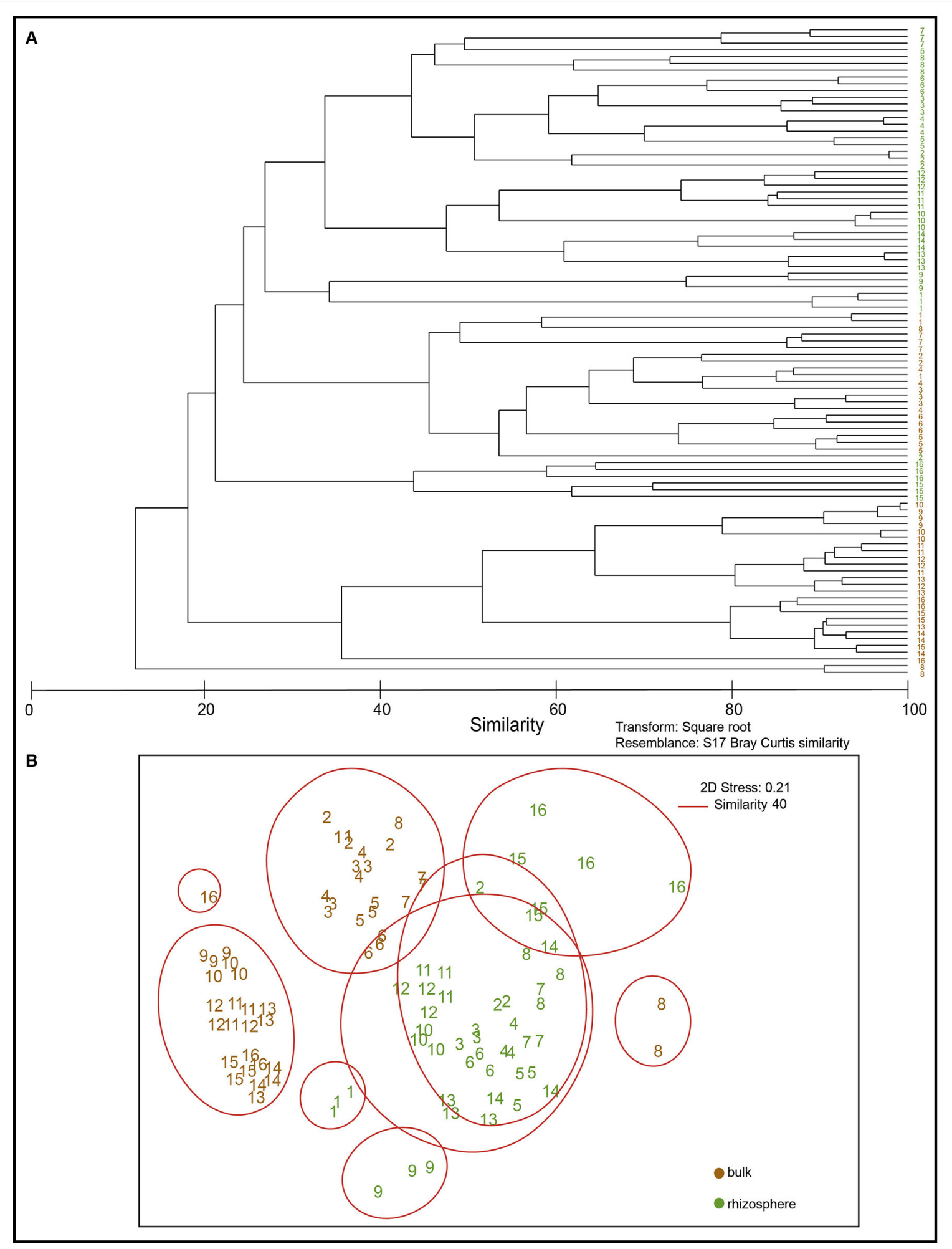

FIGURE 3 | Dendogram of DGGE profiles (A) and non-metric Multidimensional Scaling (NMDS) based on denaturing gradient gel electrophoresis (DGGE) profiles of bacterial communities present in bulk (brown) and rhizosphere (green) soil samples (B). 


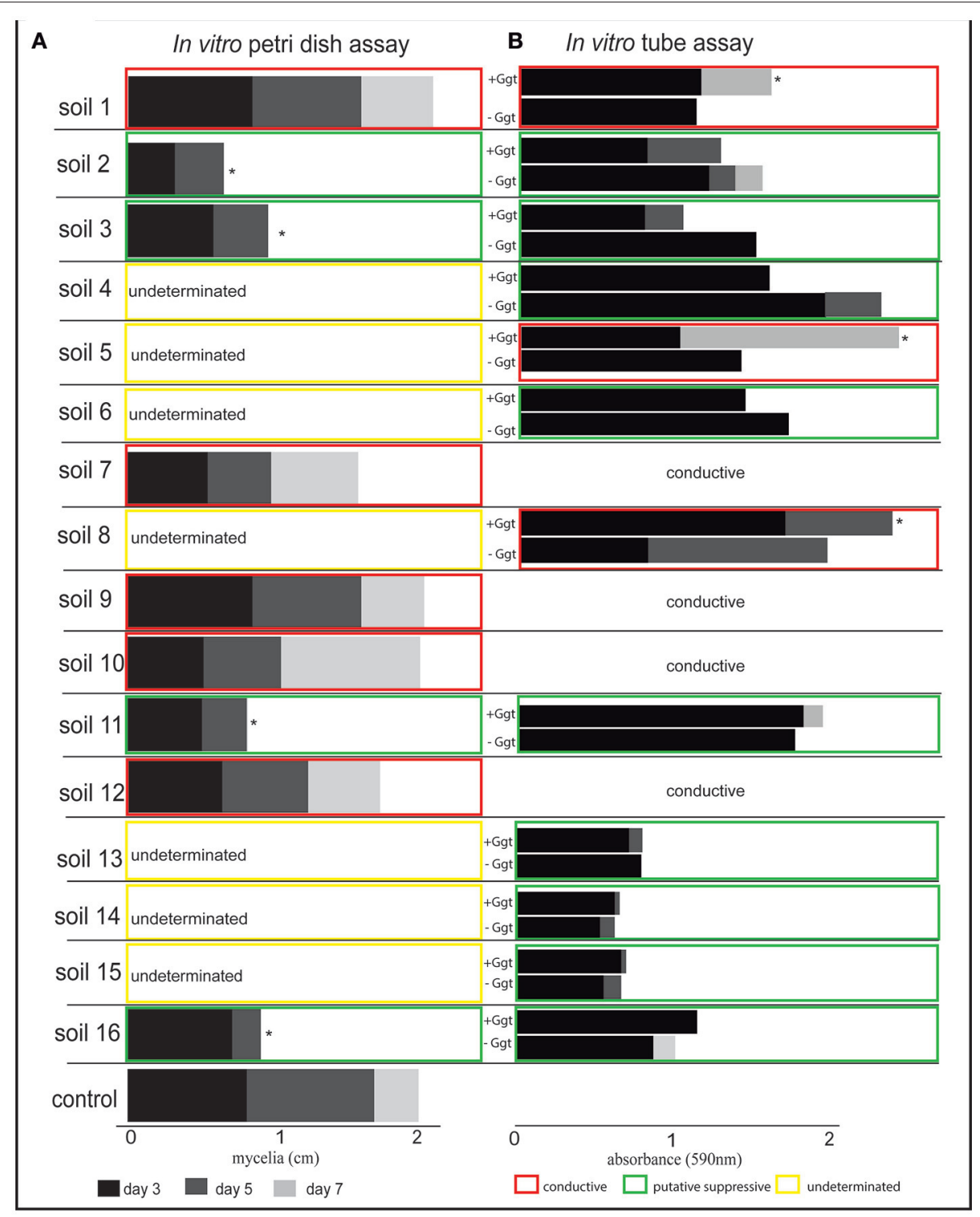

FIGURE 4 | In vitro assays to determine the inhibition of Gaeumannomyces graminis growth in the presence of rhizosphere soil samples. (A) Shows Ggt mycelial growth on solid media supplemented with the different rhizosphere soils after 3, 5, and 7 days of incubation. (B) Shows Ggt fungal biomass in liquid rhizosphere soil extracts after 3,5 , and 7 days of incubation. Asterisks indicate significant differences (Tukey's test, $p \leq 0.05$ ) in relation to the positive control (solid media assay) and negative control (liquid assay).

soils, except for soils 1, 6, and 14 (Figure 5). In fact, no significant differences were found between sterile and natural soil in the case of soils 1 and 14 (blackening roots levels ranging from 15 to $35 \%$ ).

A negative correlation between blackening roots and biomass was also observed. Thus, the lower biomass was found in the sterile Ggt-inoculated soil treatments, where plants showed higher plant infection, with the exception, again, of soils 6 and 14 , in which plant biomass was similar in sterile and natural soils (Figure 6). In treatments where a $1 \%$ of the natural soils was added to the sterile soils, biomass production increased significantly $(P \leq 0.05)$. In fact, in soils 4,13 , and 15 the highest biomass for this treatment was found, being similar in the rest of the soils. Only in soil 1 (Ggt-conducive positive control) plant biomass was lower in the $1 \%$ natural soil supplemented treatment.

\section{Presence of 2,4-DAPG Producing Bacteria}

2,4-DAPG-producing bacteria have been reported as major takeall disease suppressors in soils (Kwak et al., 2012). Accordingly, we checked for their presence in our selected suppressive soils. However, we found that only soil 15 was positive for the phlD gene, essential in the DAPG biosynthetic pathway (Gardener et al., 2001). The rest of suppressive soil samples did not show the presence of amplicons for this gene (Supplementary Figure 5), 


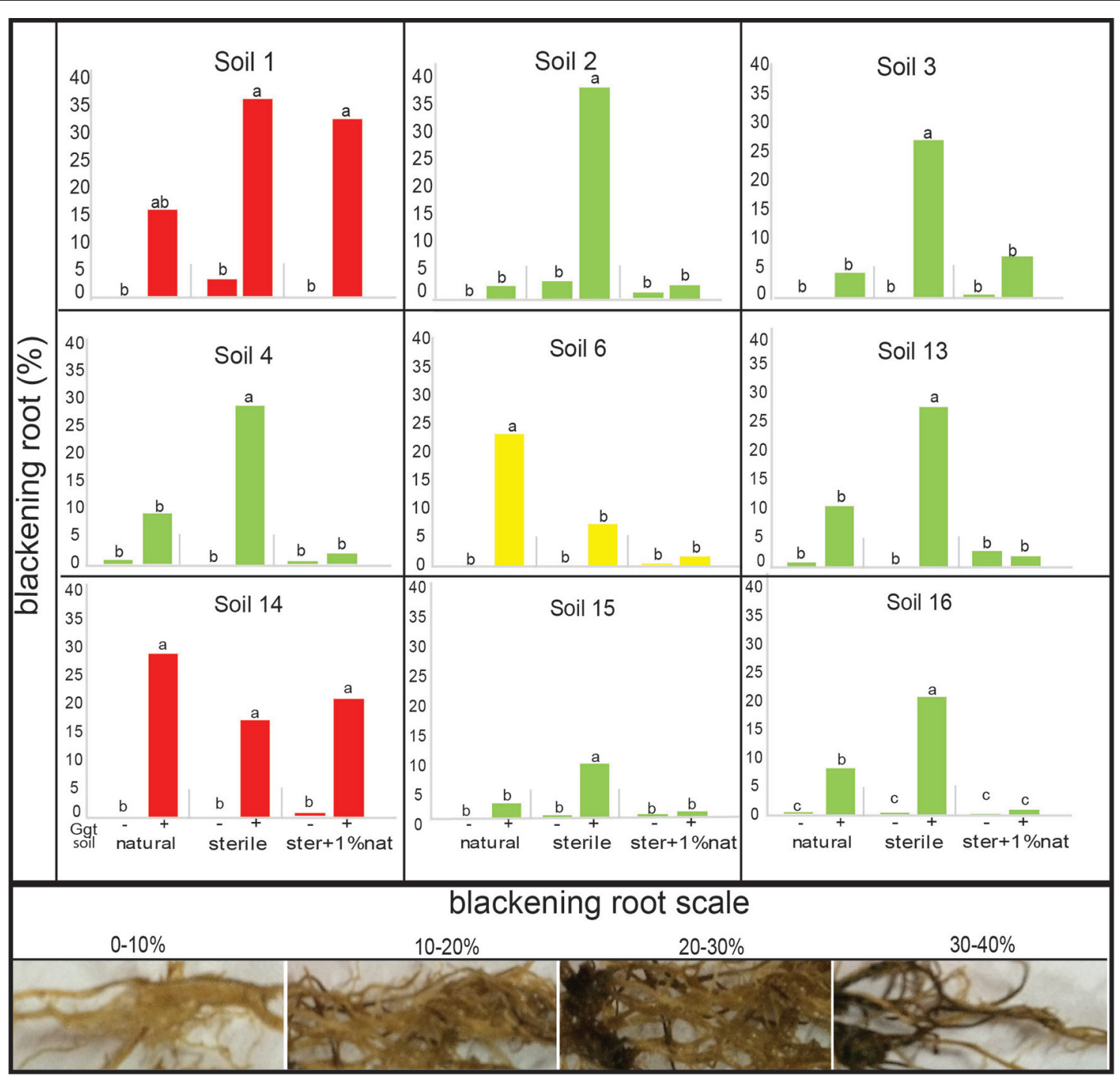

FIGURE 5 | Take all disease symptoms (root blackening) in wheat plants from the suppressive soil bioassay in greenhouse. Treatments were: natural soil (natural), sterile soil (sterile), and sterile soil supplemented with $1 \%$ of natural soil (ster $+1 \%$ nat), inoculated $(+)$ or not $(-)$ by Ggt $(n=5)$. The disease index scale used is represented by the pictures in the bottom panel. Tukey's test was used to compare treatments means, values followed by the same letter do not differ at $P \leq 0.05$ $(n=5)$. Green bars represent suppressive soils, red bars conducive soils, and yellow bars represent undeterminated soil.

suggesting that other metabolic pathways should be responsible for suppressiveness in those soils.

\section{Rhizosphere Bacterial Community Composition in Suppressive and Conducive Soils}

Regarding the composition of the rhizosphere bacterial communities (as revealed by DGGE analysis), the dendrogram showed differences between suppressive and conducive soils in the case ofAndisols (Figure 7). These results were confirmed by using MDS analysis, showing clear differences between the conducive control soil (soil 1) and the rest of treatments in Andisol (55\% similarity). However, in the case of Ultisols in which the bacterial communities were more significantly related with the soil chemical parameters than in Andisol soils (Table 3), this tendency was not observed (Figure 7B).

\section{DISCUSSION}

Several studies have described the importance of soil microorganisms as suppressive agents against phytopathogens worldwide, including soils with chemical properties similar to Chilean agricultural soils, such as, New Zealand soils (Bithell et al., 2013; Chng et al., 2013, 2015; Perez et al., 2016). However, despite of the great potential that Chilean suppressive soils offer in terms of microbial diversity and potential for the development of biocontrol strategies, their studies are extremely limited (Andrade et al., 2011). This topic acquires special relevance 


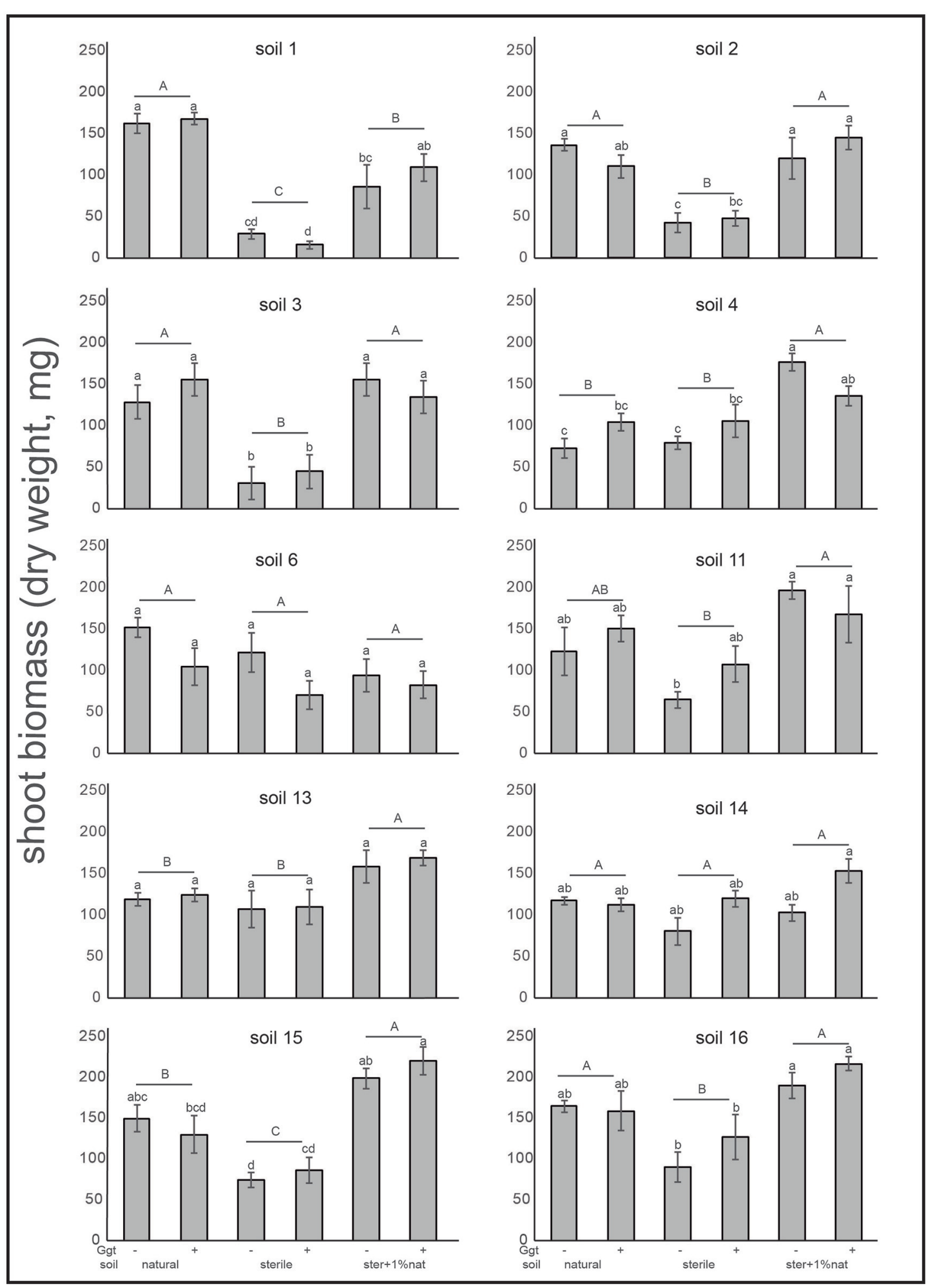

FIGURE 6 | Shoot biomass (dry weight) of wheat plants from suppressive soil assay in greenhouse. Treatments were: natural soil (natural), sterile soil (sterile), and sterile soil supplemented with $1 \%$ of natural soil (ster $+1 \%$ nat)- and inoculated ( + ) or not $(-)$ by Ggt $(n=5)$. Tukey's test was used to compare treatments means, values followed by the same letter do not differ at $P \leq 0.05(n=5)$. 


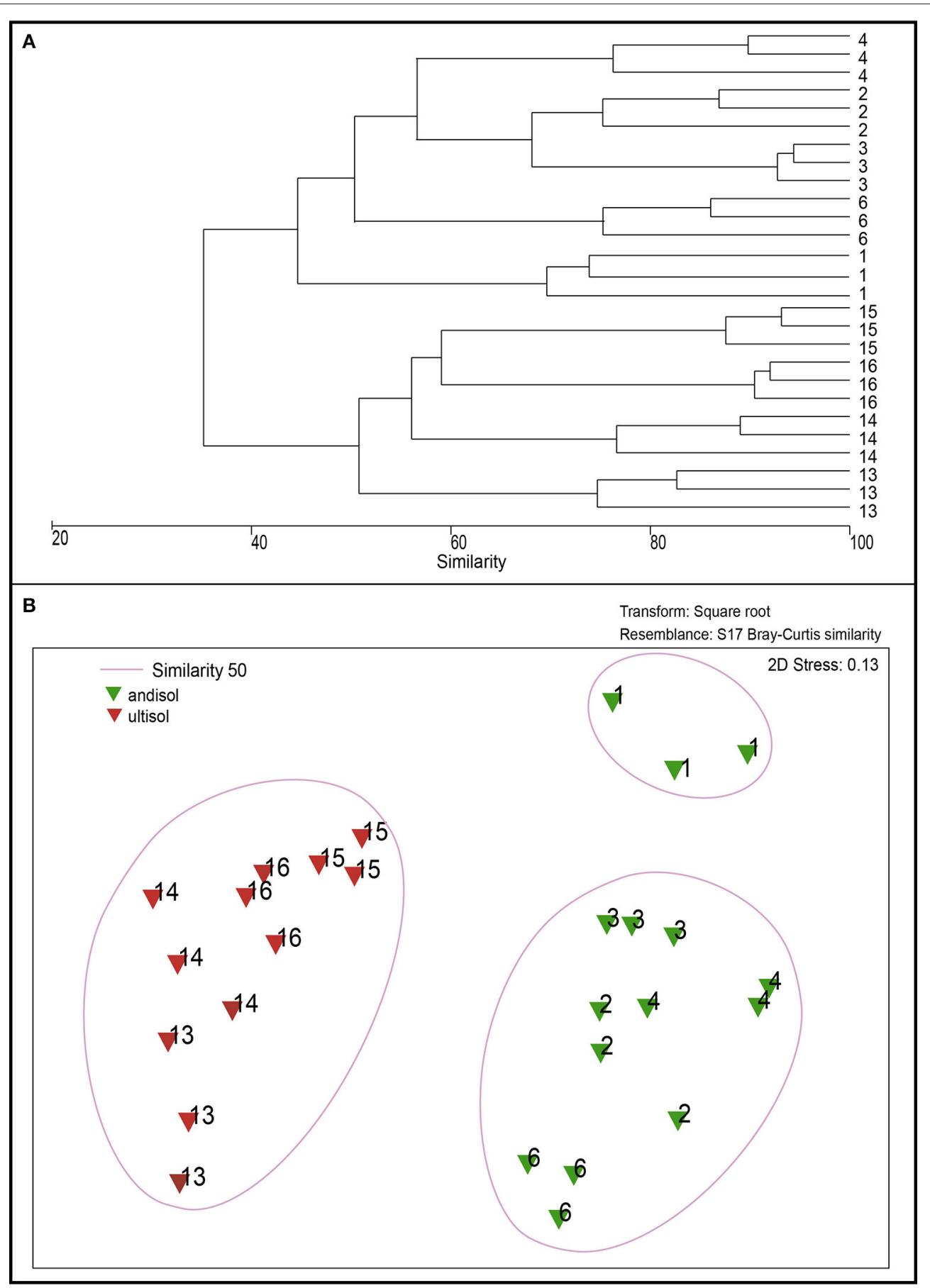

FIGURE 7 | Dendrogram of DGGE profiles (A) and non-metric Multidimensional Scaling (NMDS) analysis (B) of bacterial communities in the rhizosphere of soils from the greenhouse experiment (soils 2, 3, 4, 13, 14, 15, and 16) compared with Ggt-conducive soil (soil 1).

when ancestral extensive agriculture has been applied for a long term by native communities; Mapuche people cultivate in small areas to produce their own agricultural products using rustic metal tools and low inputs (Montalba-Navarro, 2004). This ancestral production could be replaced by more aggressive and intensive modern agriculture techniques, with the possible subsequent loss of diversity and suppressive potential of soil microbial communities. Under this scenario, it is essential to identify suppressive soils in these areas. In this work we screened the ability of different agricultural soils from southern Chile to suppress take-all disease in wheat plants. Suppressive soils were collected from little farms mainly belonging to indigenous Mapuche communities from Southern Chile, who practice monoculture and cultivate small subsistence wheat areas. 


\section{Soil Chemical Parameters and Their Relation with Microbial Community Composition}

Our results on soil chemical properties showed that $25 \%$ of the studied soils presented a low content of available $\mathrm{P}(<$ $20 \mathrm{mg} \mathrm{kg}-1$ ), moderate acidity $(\mathrm{pH}<5.5)$, and high $\mathrm{Al}$ saturation $(>10 \%)$, which are main characteristics of agricultural soils from southern Chile (Mora et al., 2006). In general, Andisols grouped together when considering the chemical parameters, whereas Ultisols were more diverse. However, when we compared microbial diversity we observed a direct correlation with soil chemistry mainly in rhizospheric soils, and more significantly for Ultisols. Similar results were found by Smalla et al. (2007) despite the amplified fragments comprised different variable regions and lengths, DGGE, T-RFLP, and SSCP analyses led to clustering of fingerprints, which correlated with soil physico-chemical properties. In Chilean Andisol soils, Jorquera et al. (2014) also showed that soil chemistry influenced the composition of rhizobacterial communities, and in Ultisol soils from China, Li et al. (2017) found through nMDS analyses that microbial communities also correlated with soil chemical parameters and fertilization strategies. Although there is some similarity in microbial composition between rhizosphere and bulk microbial composition (de Ridder-Duine et al., 2005), in our study rhizosphere soils were more diverse in terms of richness and dominance than bulk soils. In fact, it is known that the amount of microorganism around the rhizosphere is 10- to 1,000fold higher than that found in bulk soil due to rhizodeposition (Doughari, 2015; Glick, 2015).

\section{Suppressive Soil Identification in Southern Chile}

In terms of potential take-all disease suppression, in vitro Ggtgrowth inhibition tests with 16 different soils allowed to identify 9 potentially suppressive soils, and 6 of them were later confirmed to be suppressive in plant bioassays under greenhouse conditions (soil 2, 3, 4, 13, 15, and 16). In general, these soils were cultivated with wheat monoculture and natural pasture for more than 10 years, a management similar to that described previously for other suppressive soils in South Chile (Andrade et al., 2011). Regarding the timing, take-all suppression appeared after 4-6 years of wheat monoculture (McSpadden Gardener and Weller, 2001), and even later, although they can also occur in soils with 3-4 years of monoculture under relatively high pathogen concentrations (Chng et al., 2015). In fact, early studies by Baker and Cook (1974) showed that 3 years of successive wheat cropping could be sufficient for the development of specific suppression. As an exception, soil 2, withrotation based in wheattriticale and oat for more than 10 years, was also found to be Ggt-suppressive. It is well known that oat roots produce saponin avenacin, a glycosylated triterpenoid secondary metabolite with antifungal properties that has been involved in determining oat resistance to soil fungal pathogens (Osbourn et al., 1994; Freeman and Ward, 2004). On the other hand, wheat plants grown in soil 11 , characterized by a very high humidity, showed no symptoms of Ggt infection in roots. This is in agreement with earlier reports by Nish (1973), who studied Ggt survival in the field under controlled conditions, and showed a significant reduction in Ggt incidence in wet cool soils.

In greenhouse assays, wheat plants grown on sterile Ggtinoculated soils presented the highest disease incidence and the lowest biomass production, suggesting the relevance of the autochthonous soil microbial communities on plant growth promotion and disease suppression. The effect observed in sterile soils-increased susceptibility and reduced biomasswas improved when they were supplemented with $1 \%$ of the same natural soils, except in the case of the conducive soils 1 and 14. This improvement also confirms the role of the microbial communities originally present in the take-all disease suppressive soils and Ggt control. This characteristic is known as specific suppression (Cook, 2003; Andrade et al., 2011; Chng et al., 2015). It is noteworthy that we did not find any relation between suppressive soils and the presence of 2,4DAPG-producing bacteria since its presence was only detected in one out of the six confirmed suppressive soils. The low occurrence of 2,4-DAPG determined by phlD gene, suggests that other mechanism(s) or antifungal compound(s) are synthetized by native soil microorganisms that could contribute to the effective biocontrol against Ggt. Thus, strains related to soil suppressiveness seem to be differentially shaped by multiple soil factors (Imperiali et al., 2017). Therefore, further studies are required to identify the mechanisms involved in Ggt disease suppression.

\section{Suppressive Soils and Microbial Community Composition}

As mentioned above, the selected suppressive soils did not group together in relation to their chemical properties and geographical origin. However, when bacterial communities were analyzed by DGGE, within Andisols, suppressive soils grouped separately with respect to the control conducive soil 1 , but not for Ultisols, in which suppressive soils grouped together with soil 14, also classified as conducive. This could be attributed to the high relation between Ultisol soils and soil chemical parameters when compared to that relation in Andisol soils $\left(r^{2}=0.90\right.$ and 0.59 , respectively). Future research should explore which specific microbial groups act directly upon Ggt suppression and how rhizosphere microbial communities are selected and regulated by the plant rhizosphere, especially in the presence of the phytopathogens. Moreover, identifying the bacterial groups and their antagonist mechanisms, as well as exploring the potential stimulation of plant defense mechanisms are pivotal for the development of biocontrol strategies based on the use of suppressive soils. With this aim, future research should tackle the multifactor soil-microbiome-plant-pathogen systems, considering not only direct antifungal activities in the rhizosphere, but also potential stimulation of plant defense and microbe-selection mechanisms.

\section{CONCLUSIONS}

Suppressive soils represent an important microbial source for the biocontrol of soil-borne pathogens, and their identification and characterization is crucial since many of these soils may be lost 
by the increase of intensive agriculture practices worldwide. Here, we identified six suppressive soils against take-all disease, which have been managed under ancestral and rudimental agronomic practices by Chilean indigenous Mapuche communities. Then, we showed that suppressive activity in the tested soils correlated with the microbial community composition and not with the chemical properties and geographical origin of the studied soils. The key role of the soil microbial communities in Ggt suppression was confirmed in assays with sterile (heat-treated) suppressive soils where Ggt suppresiveness was completely lost, and recovered again through the addition of $1 \%$ of the corresponding non sterile natural suppressive soil. Our understanding of microbial communities in suppressive soils as well as the mechanisms acting in disease suppression in the rhizosphere must be considered as a valuable tool for the development of sustainable control of soil-borne pathogen (such as, take-all disease) in agriculture.

\section{AUTHOR CONTRIBUTIONS}

PD, SV, MJ, MM designed the research. MP and VC supervised the study. PD organized the soil sampling and chemical soil analysis. SV performed the greenhouse experiments. VC analyzed

\section{REFERENCES}

Andrade, O., Campillo, R., and Peyrelongue, A. (2011). Soils suppressive against Gaeumannomyces graminis var. tritici identified under wheat crop monoculture in southern Chile. Cs. Invest. Agric. 38, 345-356. doi: $10.4067 /$ S0718-16202011000300004

Andrade, O., Mathre, D. E., and Sands, D. C. (1994). Suppression of Gaeumannomyces graminis var tritici in montana soils and its transferability between soils. Soil. Biol. Biochem. 26, 397-402. doi: 10.1016/0038-0717(94)90289-5

Arismendi, N., Doussoulin, H., and Moya, E. (2012). "Determinación de Pseudomonas productoras de 2,4 diacetilfloroglucinol en cultivos de trigo en el sur de Chile," in XXI Congreso Chileno de Fitopatología, 17-18-19 de octubre 2012 (Puerto Varas Chile).

Baker, K. F., and Cook, R. J. (1974). Biological Control of Plant Pathogens. San Francisco, CA: Freeman.

Bertsch, P. M., and Bloom, P. R. (1996). "Aluminum," in Methods of Soil Analysis, Part 3-Chemical Methods, ed J. M. Bigham (Madison, WI: Soil Science Society of America), 526-527.

Bithell, S. L. S., McKay, A., Butler, R., New, T., Bag, P., and Zealand, N. (2012). Predicting take-all severity in second-year wheat using soil DNA concentrations of Gaeumannomyces graminis var. tritici determined with qPCR. Plant Dis. 96, 443-451. doi: 10.1094/PDIS-05-11-0445

Bithell, S. L., Butler, R. C., McKay, A. C., and Cromey, M. G. (2013). Influences of crop sequence, rainfall and irrigation, on relationships between Gaeumannomyces graminis var. tritici and take-all in New Zealand wheat fields. Australas. Plant Pathol. 42, 205-217. doi: 10.1007/s13313-012-0168-9

Bull, C. T., Weller, D. M., and Thomashow, L. S. (1991). Relationship between root colonization and suppression of Gaeumannomyces graminis var. tritici by Pseudomonas fluorescens strain 2-79. Phytopathology 81, 954-959. doi: 10.1094/Phyto-81-954

Chng, S. F., Stewart, A., Cromey, M. G., Dodd, S. L., Butler, R. C., and Jaspers, M. V. (2013). Effects of different rates of Gaeumannomyces graminis var. tritici inoculum for detecting take-all suppression in soils. Australas. Plant Pathol. 42, 103-109. doi: 10.1007/s13313-012-0166-y

Chng, S., Cromey, M. G., Dodd, S. L., Stewart, A., Butler, R. C., and Jaspers, M. V. (2015). Take-all decline in New Zealand wheat soils and the microorganisms associated with the potential mechanisms of disease suppression. Plant Soil. 397, 239-259. doi: 10.1007/s11104-015-2620-4 the data. PD and MP wrote the manuscript and authors critically revised the manuscript and approved the final version.

\section{FUNDING}

This study was supported by the Comisión Nacional de Investigación Científica and Tecnológica (CONICYT), FONDECYT Iniciation Project No. 11150540 from Chilean Government. MJ thanks the support by FONDECYT No. 1160302. We acknowledge support of the publication fee by the CSIC Open Access Publication Support Initiative through its Unit of Information Resources for Research (URICI).

\section{ACKNOWLEDGMENTS}

We thank the technical support of the Scientific and Technological Bioresource Nucleus (BIOREN) from La Frontera University.

\section{SUPPLEMENTARY MATERIAL}

The Supplementary Material for this article can be found online at: http://journal.frontiersin.org/article/10.3389/fmicb. 2017.01552/full\#supplementary-material

Clapp, R. A. (1998). Regions of refuge and the agrarian question: peasant agriculture and plantation forestry in Chilean Araucania. World Dev. 26, 571-589. doi: 10.1016/S0305-750X(98)00010-2

Clarke, K. R. (1993). Non-parametric multivariate analyses of changes in community structure. Aust. J. Ecol. 18, 117-143. doi: 10.1111/j.1442-9993. 1993.tb00438.x

Cook, R. J. (2003). Take-all of wheat. Physiol. Mol. Plant Pathol. 62, 73-86. doi: 10.1016/S0885-5765(03)00042-0

De Coninck, B., Timmermans, P., Vos, C., Cammue, B. P. A., and Kazan, K. (2015). What lies beneath: belowground defense strategies in plants. Trends Plant Sci. 20, 91-101. doi: 10.1016/j.tplants.2014.09.007

de Ridder-Duine, A. S., Kowalchuk, G. A., Gunnewiek, P. J. A. K., Smant, W., Van Veen, J. A., and de Boer, W. (2005). Rhizosphere bacterial community composition in natural stands of Carex arenaria (sand sedge) is determined by bulk soil community composition. Soil Biol. Biochem. 37, 349-357. doi: $10.1016 /$ j.soilbio.2004.08.005

Doughari, J. (2015). An overview of plant immunity. J. Plant Pathol. Microbiol. 6:11. doi: 10.4172/2157-7471.1000322

Durán, P., Acuña, J. J., Jorquera, M. A., Azcón, R., Paredes, C., Rengel, Z., et al. (2014). Endophytic bacteria from selenium-supplemented wheat plants could be useful for plant-growth promotion, biofortification and Gaeumannomyces graminis biocontrol in wheat production. Biol. Fertil. Soils 50, 983-990. doi: 10.1007/s00374-014-0920-0

Fouly, M., and Wilkinson,T. (2000). Detection of Gaeumannomyces graminis varieties using polymerase chain reaction with variety-specific primers. Plant Dis. 84, 947-951. doi: 10.1094/PDIS.2000.84.9.947

Freeman, J., and Ward, E. (2004). Gaeumannomyces graminis, the take-all fungus and its relatives. Mol. Plant Pathol. 5, 235-252. doi: 10.1111/j.1364-3703.2004.00226.x

French, S., Levy-Booth, D., Samarajeewa, A., Shannon, K. E., Smith, J., and Trevors, J. T. (2009). Elevated temperatures and carbon dioxide concentrations: effects on selected microbial activities in temperate agricultural soils. World J. Microbiol. Biotechnol. 25, 1887-1900. doi: 10.1007/s11274-0090107-2

Gardener, B. B. M., Mavrodi, D. V., Thomashow, L. S., and Weller, D. M. (2001). A rapid polymerase chain reaction-based assay characterizing rhizosphere populations of 2.4-diacetylphloroglucinol-producing bacteria. Phytopathology 31, 44-54. doi: 10.1094/PHYTO.2001.91.1.44

Glick, B. R. (2015). Beneficial Plant-Bacterial Interactions. London: Springer. 
Imperiali, N., Dennert, F., Schneider, J., Laessle, T., Mavrodi, D., Maurhofer, M., et al. (2017). Relationships between root pathogen resistance, abundance and expression of Pseudomonas antimicrobial genes, and soil properties in representative swiss agricultural soils. Front. Plant Sci. 8:427. doi: $10.3389 /$ fpls.2017.00427

Iwamoto, T., Tani, K., Nakamura, K., Suzuki, E., Kitagawa, M., Eguchi, M., et al. (2000). Monitoring impact of in situ biostimulation treatment on groundwater bacterial community by DGGE. FEMS Microbiol. Ecol. 32, 129-141. doi: 10.1111/j.1574-6941.2000.tb00707.x

Jara, D., Herman, A., Elizondo, M., and Ernesto, A. (2011). Root disease suppressive soils: "Take all decline (Gaeumannomyces graminis var. tritici) in wheat. A. Agro Sur. 39, 67-78. doi: 10.4206/agrosur.2011.v39n2-01

Jorquera, M. A., Marileo, L. G., Acuna, J. J., and Saggar, S. (2014). Effect of nitrogen and phosphorus fertilization on the composition of rhizobacterial communities of two Chilean Andisol pastures. World J. Microbiol. Biotechnol. 30, 99-107. doi: 10.1007/s11274-013-1427-9

Kwak, Y.-S., Bonsall, R. F., Okubara, P. A., Paulitz, T. C., Thomashow, L. S., and Weller, D. M. (2012). Factors impacting the activity of 2,4diacetylphloroglucinol-producing Pseudomonas fluorescens against take-all of wheat. Soil Biol. Biochem. 54, 48-56. doi: 10.1016/j.soilbio.2012.05.012

Lee, C. H., Barbier, B., Bottos, E., McDonald, I., and Craig-Cary, S. (2012). The inter-valley soil comparative survey: the ecology of dry valley edaphic microbial communities. ISME J. 6, 1046-1057. doi: 10.1038/ismej.2011.170

Li, L., Fan, F., Song, A., Yin, C., Cui, P., and Li, Z. (2017). Microbial composition and diversity are associated with plant performance: a case study on long-term fertilization effect on wheat growth in an Ultisol. Appl. Microb. Cell Physiol. 101, 4669-4681. doi: 10.1007/s00253-017-8147-2

Liu, B., Huang, L., Kang, Z., and Buchenauer, E. (2011). Evaluation of endophytic bacterial strains as antagonists of take-all in wheat caused by Gaeumannomyces graminis var. tritici in greenhouse and field. J. Pest. Sci. 84, 257-264. doi: 10.1007/s10340-011-0355-4

Macia-Vicente, J. G., Janson, H.-B., Mendgen, K., and Lopez-llorca, L. V. (2008). Colonization of barley roots by endophytic fungi and their reduction of take-all caused by Gaeumannomyces graminis var. tritici. Can. J. Microb. 609, 600-609. doi: 10.1139/W08-047

Manici, L. M., Bregaglio, S., Fumagalli, D., and Donatelli, M. (2014). Modelling soil borne fungal pathogens of arable crops under climate change. Int. J. Biometeorol. 58, 2071-2083. doi: 10.1007/s00484-014-0808-6

Mavrodi, D. V., Mavrodi, O. V., Parejko, J. A., Bonsall, R. F., Kwak, Y. S., Paulitz, T. C., et al. (2012). Accumulation of the antibiotic phenazine- 1-carboxylic acid in the rhizosphere of dryland cereals. Appl. Environ. Microbiol. 78, 804-812. doi: 10.1128/AEM.06784-11

McSpadden Gardener, B. B., and Weller, D. M. (2001). Changes in populations of rhizosphere bacteria associated with take-all disease of wheat. Appl. Environ. Microbiol. 67, 4414-4425. doi: 10.1128/AEM.67.10.4414-4425.2001

Mendes, R., Garbeva, P., and Raaijmakers, J. M. (2013). The rhizosphere microbiome: significance of plant beneficial, plant pathogenic, and human pathogenic microorganisms. FEMS Microbiol. Rev. 37, 634-663. doi: 10.1111/1574-6976.12028

Mendes, R., Kruijt, M., and de Bruijn, I. (2011). Deciphering the rhizosphere microbiome for disease-suppressive bacteria. Science 332, 1097-1100. doi: $10.1126 /$ science. 1203980

Meza, F., and Silva, D. (2009). Dynamic adaptation of maize and wheat production to climate change. Clim. Change 94, 143-156. doi: 10.1007/s10584-009-9544-z

Montalba-Navarro, R. (2004). Transformación de los agroecosistemas y degradación de los recursos naturales en el territorio mapuche: una aproximación histórico- ecológica. CUHSO 8, 19-40. doi: 10.7770/ cuhso-V8N1-art201

Mora, M. L., Alfaro, M. A., Jarvis, S. C., Demanet, R., and Cartes, P. (2006). Soil aluminium availability in Andisols of southern Chile and its effect on forage production and animal metabolism. Soil Use Manage. 22, 95-101. doi: 10.1111/j.1475-2743.2006.00011.x

Mora, L., Demanet, R., Acuña, J. J., Viscardi, S., Jorquera, M., Rengel, Z., et al. (2017). Aluminum-tolerant bacteria improve the plant growth and phosphorus content in ryegrass grown in a volcanic soil amended with cattle dung manure. Appl. Soil Ecol. 115, 19-26. doi: 10.1016/j.apsoil.2017.03.013

Moya-Elizondo, E., Arismendi, N., Castro, M. P., and Doussoulin, H. (2015).Distribution and prevalence of crown rot pathogens affecting wheat crops in southern Chile. Chilean J. Agric. Res. 75, 78-84. doi: $10.4067 /$ S0718-58392015000100011
Murphy, J., and Riley, J. P. (1962). A modified single solution method for the determination of phosphate in natural waters. Anal. Chim. Acta 27, 31-36. doi: 10.1016/S0003-2670(00)88444-5

Neuenschwander, A. (2010). El Cambio Climático en el Sector Silvoagropecuario de Chile. Santiago: Salviat, S. A.

Nish, M. (1973). Survival of Gaeumannomyces graminis var tritici in field soil stored in controled environments. Aust. J. Biol. Sci. 27, 2143-2145.

ODEPA, (2016). Oficina de Estudios y Políticas Agrarias. ODEPA, Santiago, Chile. Available online at: http://www.odepa.cl/rubro/cereales/ (Accessed March 2017).

Osbourn, A. E., Clarke, B. R., Lunness, P., Scott, P. R., and Daniels, M. J. (1994). An oat species lacking avenacin is susceptible to infection by Gaeumannomyces graminis var. tritici. Physiol. Mol. Plant Pathol. 45, 457-467. doi: 10.1016/S0885-5765(05)80042-6

Perez, C. A., Aravena, J. C., Silva, W. A., McCulloch, R., Armesto, J. J., and Parfitt, R. (2016). Patterns of ecosystem development in glacial foreland chronosequences: a comparative analysis of Chile and New Zealand. N.Z. J. Bot. 54, 156-174. doi: 10.1080/0028825X.2016.11 43018

Sagar, R., and Sharma, G. (2012). Measurement of alpha diversity using Simpson index (1/ $\lambda)$ : the jeopardy. Environ. Skep. Crit. 1, 23-24.

Shipton, P. J., Cook, R. J., and Sitton, J. W. (1973). Occurrence and transfer of a biological factor in soil that suppresses take-all of wheat in eastern Washington. Phytopathology 63, 511-517.

Silva, S., Henriques, M., Martins, A., Oliveira, R., Williams, D., and Azeredo, J. (2009). Biofilms of non-Candida albicans Candida species: quantification, structure and matrix composition. Med. Mycol. 47, 681-689. doi: $10.3109 / 13693780802549594$

Smalla, K., Oros-Sichler, M., Milling, A., Heuer, E., Baumgarte, S., Becker, R., et al. (2007). Bacterial diversity of soils assessed by DGGE, T-RFLP and SSCP fingerprints of PCR-amplified 16S rRNA gene fragments: do the different methods provide similar results? J. Microb. Methods 69, 470-479. doi: 10.1016/j.mimet.2007.02.014

Soussana, J. F., Graux, A. I., and Tubiello, F. N. (2010). Improving the use of modelling for projections of climate change impacts on crops and pastures. J. Exp. Bot. 61, 2217-2228. doi: 10.1093/jxb/erq100

Taylor, G. J., and Foyd, C. D. (1985). Mechanisms of aluminium tolerance in Triticum aestivum (wheat). II. Differential $\mathrm{pH}$ induced by winter cultivars in nutrient solutions. Am. J. Bot. 72, 695-701. doi: 10.2307/24 43681

Walkley, A., and Black, I., A. (1934). An examination of Degtjareff method for determining soil organic matter and a proposed modification of the chromic acid titration method. Soil Sci. 37, 29-37. doi: 10.1097/00010694-193401000-00003

Warncke, D., and Brown, J. R. (1998). "Potassium and other basic cations," in Recommended Chemical Soil Test Procedures for the North Central Region NCR Publication No. 221, ed J. R. Brown (Columbia, MO: Missouri Agricultural Experiment Station), 31-33.

Weller, D. M., Mavrodi, D. V., van Pelt, J. A., Pieterse, C. M., van Loon, L. C., and Bakker, P. A. (2012). Induced systemic resistance in Arabidopsis thaliana against Pseudomonas syringae pv. tomato by 2,4diacetylphloroglucinol-producing Pseudomonas fluorescens. Phytopathology 102, 403-412. doi: 10.1094/PHYTO-08-11-0222

Weller, D. M., Raaijmakers, J. M., Gardener, B. B. M., and Thomashow, L. S. (2002). Microbial populations responsible for specific soil suppressiveness to plant pathogens. Annu. Rev. Phytopathol. 40, 309-334. doi: 10.1146/annurev.phyto.40.030402.110010

Conflict of Interest Statement: The authors declare that the research was conducted in the absence of any commercial or financial relationships that could be construed as a potential conflict of interest.

Copyright $\odot 2017$ Durán, Jorquera, Viscardi, Carrion, Mora and Pozo. This is an open-access article distributed under the terms of the Creative Commons Attribution License (CC BY). The use, distribution or reproduction in other forums is permitted, provided the original author(s) or licensor are credited and that the original publication in this journal is cited, in accordance with accepted academic practice. No use, distribution or reproduction is permitted which does not comply with these terms. 